\title{
Platão contra um certo platonismo: a crítica da hipótese das Ideias no Parmênides
}

\author{
Plato against a certain platonism: the criticism of the hypothesis of Ideas in the \\ "Parmenides"
}

\section{Marcio Soares ${ }^{\mathrm{I}}$}

Resumo: Apresento nesse texto uma leitura da primeira parte (127a-135c) do diálogo Parmênides. Meu objetivo é demonstrar a possibilidade de que as críticas objetadas pelo velho Parmênides à hipótese platônica das Ideias, exposta e defendida pelo jovem Sócrates, não são letais à mesma hipótese, uma vez que estão assentadas em dois pressupostos que a ela são alheios e desnecessários. Primeiro, a pressuposição de Parmênides de que a "distinção" (diéiresai) entre Ideias e coisas delas participantes seja equivalente a total "separação" (chorís) entre ambas (Prm. 13ob). Segundo, o fato de que o Eleata, na construção de seus argumentos, trata das Ideias como se fossem coisas materiais, isto é, tais como as coisas que são objetos de nossa percepção sensível. Pretendo mostrar de que forma esses dois pressupostos sustentam as dificuldades teóricas decorrentes das perguntas dirigidas por Parmênides a Sócrates, as quais esse último não consegue responder. Ao final, minha sugestão é de que Platão tenha posto na boca do velho Eleata uma interpretação errônea de sua própria hipótese das Ideias. Nesse sentido, nosso Filósofo, no diálogo Parmênides, estaria combatendo um certo platonismo.

Palavras-chave: Hipótese das Ideias; Crítica; Parmênides; Platão; Platonismo

Abstract: I present in this text a reading of the first part (127a-135c) of the Parmenides dialogue. My purpose is to demonstrate the possibility that the criticisms objected by the old Parmenides to the Platonic hypothesis of Ideas, exposed and defended by the young Socrates, are not lethal to the same hypothesis, since they are based on two presuppositions that are extraneous and unnecessary to it. First, Parmenides' assumption that the "distinction" (diéiresai) between Ideas and things that participate of them is equivalent to a total "separation" (choris) of both (Prm. 13ob). Second, the fact that the Eleatic, in constructing his arguments, treats the Ideas as if they were material things, that is, such as the things that are objects of our sensory perception. I intend to show how these two assumptions support the theoretical difficulties arising from the questions addressed by Parmenides to Socrates, which the latter cannot answer. In the end, my suggestion is that Plato put into the mouth of the old Eleatic an erroneous interpretation of his own hypothesis of Ideas. In this sense, our Philosopher, in the Parmenides dialogue, would be fighting a certain platonism.

Keywords: Hypothesis of Ideas; Criticism; Parmenides; Plato; Platonism

Contudo, parece-me estar eu passando o mesmo que o cavalo de Íbico [...] pronto para competir, e tremendo, por conta de sua experiência, diante do que estava para acontecer [...] como deve alguém [...] atravessar a nado tal e tão grande oceano de argumentos? (Prm. 136e-137a)

O Parmênides de Platão é uma peça sui generis dentre os diálogos escritos pelo Filósofo de Atenas, seja pelo seu conteúdo, seja pela sua forma. Provavelmente fora a densidade e aridez da segunda parte de tal texto (Prm. 135c-166c) que motivaram a fama de

\footnotetext{
${ }^{\text {I }}$ Professor de Filosofia na Universidade Federal da Fronteira Sul, Erechim, RS. E-mail: soares.uffs@gmail.com ORCID: https://orcid.org/oooo-0001-8921-3173b
} 
ser esse um dos diálogos platônicos mais difíceis, senão o mais difícil, desde a Antiguidade. Contudo, parece que, em nossa própria época, pelo menos desde meados do século XIX, é a primeira parte do mesmo texto (Prm. 127a-135c) a que tem causado mais polêmica. E tal não se deve apenas ao simples fato de que em tais páginas Platão dedique-se à sua mais famosa hipótese, a das Ideias (ou Formas), a qual sempre fora identificada e até mesmo confundida com o próprio platonismo. O motivo da polêmica contemporânea se deve, parece-me, muito mais à qualidade de tal abordagem, seja em função de sua forma, seja em função de seu conteúdo. Dito de outro modo, o motivo da polêmica deve-se ao próprio tratamento dado por Platão à sua hipótese das Ideias na primeira parte do Parmênides.

No que diz respeito à forma, nosso Filósofo aborda a hipótese das Ideias, aqui, em uma versão propriamente teórica, como a denominamos hoje - aliás, talvez essa seja uma das poucas passagens platônicas que mais poderiam justificar a famosa expressão moderna "teoria das Ideias", que tanto sucesso fez entre os scholars da obra de Platão desde meados do século XIX, mas que nunca fora empregada textualmente pelo próprio Filósofo. À parte disso, e na tentativa de apontar com clareza o que quero destacar, aqui, ao falar em versão teórica da hipótese das Ideias (essa última, sim, uma expressão tipicamente platônica), quero ressaltar o fato de que no Parmênides Platão não lança mão da mesma hipótese a fim de tratar de outra questão maior (ou simplesmente motivadora do diálogo), como ocorre no Fédon, v.g., onde tal hipótese é empregada no contexto das provas da imortalidade da alma; ou na República, outro caso, onde a mesma hipótese é central para a descrição da natureza do filósofo e da filosofia e suas consequentes justificativas para o projeto educacional e político daquela grande obra - e, exatamente por isso, a hipótese das Ideias é lá encenada na grandiloquência das inesquecíveis imagens do Sol, da Linha Dividida e da Caverna. Isso apenas para citar dois grandes exemplos, paradigmáticos e bastante conhecidos. Mas, voltemos ao Parmênides: neste diálogo, além de uma questão eleática inicial (à qual voltarei a tratar adiante), a hipótese das Ideias parece ser tomada em si e por si mesma. E ainda que consideremos a mencionada questão eleática como o principal motivo da exposição da hipótese das Ideias, tal questão (eleática) é tão teórica - como veremos - que parece determinar toda a abordagem subsequente da própria hipótese platônica das Ideias. Assim, quando me refiro, aqui, ao aspecto teórico da abordagem da hipótese das Ideias no Parmênides, também é no sentido de distingui-la de abordagens com outros objetivos, que não são puramente teóricos, como os motivos metafísicos (ou religiosos) do Fédon ou, mais claramente ainda, os motivos políticos, éticos e educacionais - portanto práticos - da República.

Mas não são apenas a forma e o motivo pelos quais a hipótese das Ideias é exposta e abordada no Parmênides que denotam a marca predominantemente teórica desse diálogo, sobretudo quando contrastado com outras peças de Platão, como o Fédon e a República. Pois, no que diz respeito à abordagem especificamente teórica das Ideias no Parmênides, o conteúdo de tal texto é mais sintomático ainda, já que se trata de verificar a própria viabilidade teórica da hipótese das Ideias em si e por si mesma. Ora, a (possível) viabilidade teórica das Ideias é terrivelmente posta em xeque nas objeções dirigidas pelo velho Parmênides de Eleia à hipótese exposta pelo então jovem Sócrates - ambos personagens platônicos no diálogo em questão. Nomeadamente, e nessa ordem, trata-se dos seguintes problemas, objetados pelo Eleata: (1) a extensão ou escopo das Ideias - ou, afinal, quais Ideias existem mesmo, relativamente a que classe de coisas? (2) as possíveis relações de participação (e suas dificuldades aparentemente inerentes e inevitáveis) entre Ideias unas e coisas múltiplas; (3) as ameaças de regressão infinita na postulação de Ideias, como intermináveis níveis de realidade sobrepostos (trata-se de diferentes versões do conhecido argumento do "terceiro homem", como o denominou Aristóteles, provavelmente após à 
escritura do Parmênides); (4) a necessidade ontológica das Ideias e a (im)possibilidade de serem elas apenas pensamentos (ou representações mentais, como poderíamos denominalos hoje); (5) por fim, a assustadora possibilidade de as Ideias estarem completamente separadas das coisas múltiplas (supostamente) delas participantes, o que inutilizaria as primeiras como causas ontológicas das segundas, e a consequente incognoscibilidade das próprias Ideias para nós, que estamos encerrados entre as coisas múltiplas (distintas e separadas das Ideias). Só essa última objeção, sozinha, tem potencial de inutilizar completamente a hipótese das Ideias, seja na condição de uma teoria ontológica, seja como uma teoria epistemológica.

Ao final do diálogo travado na primeira parte da peça (Prm. 127a-135c), todos esses problemas listados acima parecem ser insolúveis para o jovem Sócrates, que chega a transparecer desânimo e disposição para simplesmente abandonar a hipótese das Ideias por ele recém exposta e defendida. $\mathrm{O}$ velho Parmênides, então, surpreendentemente, procura injetar ânimo em Sócrates e o exorta a exercitar-se mais na prática da filosofia, sugerindo-lhe não abandonar tão facilmente a hipótese das Ideias, sob pena de inviabilizar o pensamento (diánoia) e o próprio emprego dialógico (dialégesthai) da linguagem (Prm. 135b-c).

Para nós, leitores e espectadores desse drama filosófico encenado pelo jovem Sócrates, restam algumas perguntas: o que Platão objetivou com isso tudo? Teria ele apontado para a falência teórica de sua própria hipótese das Ideias? Ou teria ele apenas submetido sua hipótese ao teste teórico mais rigoroso possível? Quais eram afinal seus objetivos: desconstruir sua própria hipótese das Ideias ou apenas testá-la na mais alta temperatura? Nesse sentido, estaria o nosso Filósofo, indiretamente, apontando o modo de não lermos sua hipótese das Ideias? Estaria ele, já em sua própria época, lutando com uma interpretação corrente e desvirtuada de sua hipótese? Seria sua abordagem crítica uma espécie de antídoto contra uma tal interpretação desvirtuada?

Independentemente das respostas dadas a todas essas perguntas, e das intenções de Platão - inescrutáveis para nós - ao escrever o Parmênides, fato é que em nenhum outro texto o nosso Filósofo fora tão rigoroso e até mesmo implacável com uma hipótese sua. Mais ainda, poucos filósofos da Tradição Ocidental foram tão exigentes consigo mesmos, como é o caso de Platão no Parmênides. Enfim, parece-me, é essa atitude radicalmente crítica do Filósofo com sua própria hipótese das Ideias, no Parmênides, e a inevitável e imensa sombra de dúvidas que a cobre, que tem despertado tanto interesse e polêmica em torno desse diálogo (especialmente de sua primeira parte), já há bem mais de um século, entre estudantes, scholars, especialistas e leitores modernos atentos do nosso Autor.

Feita essa breve exposição da abordagem teórica da hipótese das Ideias presente na primeira parte do Parmênides, quero oferecer uma sugestão de leitura e pistas para uma interpretação da mesma passagem do texto platônico. Antes disso, contudo, três perguntas cruciais devem ser repostas, a saber: (1) Platão estaria criticando sua própria hipótese das Ideias (ou submetendo-a a um exame crítico rigoroso), no sentido de reconhecer riscos e equívocos que ela mesma carrega, os quais, por assim dizer, lhe são congêneres, talvez inevitavelmente presentes em sua linguagem e em seus pressupostos teóricos? (2) Quisera o Filósofo alertar-nos, no Parmênides, a seu modo, sobre tais riscos e equívocos? (3) Assumamos, pois, ainda a título de conjectura inicial, que Platão tenha reconhecido esses riscos e equívocos presentes em sua hipótese das Ideias; nesse caso, sua abordagem no Parmênides é uma evidência suficiente de que o próprio Autor, a partir desse diálogo, 
abandonara (ou de que, pelo menos, teria motivos para abandonar) sua hipótese mais característica, isto é, a das Ideias? Em minha sugestão de interpretação da primeira parte do Parmênides, tendo a responder afirmativamente para as perguntas (1) e (2), e negativamente para a pergunta (3). Ou seja, Platão reconhece riscos e equívocos presentes na sua construção teórica da hipótese das Ideias. Nesse sentido, as críticas feitas pelo velho Parmênides à hipótese exposta pelo jovem Sócrates na primeira parte do diálogo são o diagnóstico preciso de tais riscos e equívocos. Mas, embora esses últimos estejam presentes na construção teórica da hipótese das Ideias, na forma de pressupostos e condicionantes (inclusive linguísticos) da hipótese, eles o estão de forma latente, talvez até mesmo de forma dormente, e só são ativados por interpretações que os assumam, quer ou não como equívocos. Dito de outro modo, Platão parece reconhecer que sua construção teórica da hipótese das Ideias deixa margem para que a mesma seja interpretada segundo tais pressupostos equivocados, e exatamente nesse reconhecimento reside sua autocrítica. Contudo, uma vez que são algumas interpretações dos leitores de Platão (talvez a maioria, já na época em que o Parmênides fora escrito, o que poderia justificar sua própria construção) que ativam tais pressupostos equivocados da hipótese das Ideias, eles nem são necessários isto é, são totalmente evitáveis - nem são letais à própria hipótese. Daí o motivo de por que Platão não ter abandonado (nem ter razões para abandonar) a hipótese das Ideias após a autocrítica por ele levada a cabo no Parmênides.

Nesse sentido, por ora, a fim de apontar a direção de minha própria interpretação, quero apenas indicar os dois grandes problemas que determinam as interpretações equivocadas da hipótese platônica das Ideias, as quais, a meu juízo, são miradas criticamente pelo Filósofo na primeira parte do Parmênides. Tais são os mencionados problemas: primeiro, trata-se de compreendermos a natureza mesma das próprias Ideias; segundo, diz respeito à noção de "separação" (chorís) das Ideias em relação às coisas delas participantes. Em síntese, minha sugestão de leitura e interpretação da primeira parte do Parmênides é: todas as aporias estão assentadas em uma equivocada compreensão tanto da natureza das Ideias quanto de sua distinção (ou separação) em relação às coisas. Portanto, parece-me, e quero defender isso aqui, Platão, ao mesmo tempo que reconhece os riscos e, até mesmo, os equívocos de sua hipótese mais característica e os expõe, tornando-se, assim, crítico de si mesmo, também está combatendo um certo platonismo, distorcido, o qual escandalosamente ainda vigora em nossos dias (em livros, aulas, palestras e debates filosóficos), apesar da advertência platônica desde há muito presente no Parmênides. Nessa mesma direção argumentativa, sugiro que a demonstração platônica da viabilidade teórica e da necessidade filosófica da hipótese das Ideias se dá ex negativamente, isto é, ao apontar os absurdos consequentes de leituras equivocadas de sua hipótese, Platão pretenderia, assim, indicar o único sentido em que ela pode subsistir, ser explicativamente útil (para a ontologia, para a epistemologia e para suas consequências práticas) e impor-se como necessária. Em suma, ao deixar entrever as falhas das críticas à hipótese das Ideias (i.e., a incompreensão tanto da própria natureza das Ideias quanto de sua separação ou distinção chorís - em relação às coisas delas participantes), talvez Platão tivesse a esperança de nos convencer não só da viabilidade teórica da mesma, mas também de sua necessidade filosófica - e precisamente nesse sentido falei em uma demonstração platônica ex negativa da plausibilidade de sua hipótese das Ideias.

$\mathrm{Na}$ sequência deste texto, procurarei desenvolver cada um dos dois problemas fundamentais que apontei acima, e que estão na base das interpretações distorcidas da hipótese platônica das Ideias (e, portanto, das críticas a ela objetadas na primeira parte do Parmênides), a saber, (1) a questão da distinção ou separação (chorís) entre Ideias unas e coisas múltiplas e (2) a natureza ou estatuto ontológico das próprias Ideias. Embora eu 
proponha essa distinção didática entre esses dois problemas, e nessa ordem, veremos que eles estão entrelaçados, e que o tratamento de um geralmente implica o tratamento concomitante do outro. Assim, tratarei desses problemas, expondo-os e examinando suas consequências, no contexto das próprias cinco ou seis críticas presentes na primeira parte do Parmênides (127a-135c), com o objetivo claro de desconstruir essas críticas na mesma medida em que aqueles problemas vão sendo elucidados e bem compreendidos.

Além disso, tentarei mostrar que alguns aspectos cênicos do diálogo são determinantes para a compreensão e avaliação do potencial crítico das supostas cinco ou seis objeções presentes na primeira parte da peça. Refiro-me ao fato específico de que é o ilustre Parmênides quem faz certas perguntas, as quais parecem direcionar fortemente o jovem Sócrates a dar certas respostas. Nesse sentido, é notável - e não pode ser simplesmente ignorado - o fato de que o inexperiente Sócrates é incapaz de fazer frente ou resistência ao ataque crítico e tendencioso (em uma direção que procurarei mostrar) do renomado Eleata.

Através desses procedimentos todos, tenho esperança tanto de demonstrar que as críticas do Parmênides não são letais à própria hipótese platônica das Ideias quanto de apontar a viabilidade teórica dessa última, haja vista a preservação de sua coerência lógica interna, ainda que não concordemos com ela e prefiramos, ao final, rejeitá-la como um todo.

\section{III}

Antes, contudo, cabe uma rápida abordagem da questão eleática que enseja a discussão filosófica no Parmênides, e que talvez seja o verdadeiro leitmotiv do diálogo como um todo ${ }^{1}$. No contexto dramático dessa peça, a exposição da hipótese das Ideias por Sócrates é uma reação contra-argumentativa à leitura da primeira hipótese do primeiro argumento do livro de Zenão de Eleia, recém feita pelo próprio autor. Tal hipótese zenoniana, conforme a reconstrução do jovem Sócrates, rezava o seguinte:

[...] se os seres são múltiplos [ei pollà esti tà ónta], então é preciso que eles sejam tanto semelhantes quanto dessemelhantes, mas [...] isso é impossível [adýnaton], pois nem as coisas dessemelhantes podem ser semelhantes nem as semelhantes, dessemelhantes? [...] Então, se é impossível as coisas

\footnotetext{
${ }^{1} \mathrm{O}$ encontro de Sócrates com Parmênides e Zenão de Eleia talvez aponte o verdadeiro leitmotiv de toda a construção filosófica do diálogo platônico Parmênides, a saber, o acerto de contas de Platão com o eleatismo e esse acerto de contas não se encerra nessa peça, mas alcança sua culminância em outra que dramaticamente a segue: o Sofista. Em ambos esses dois diálogos, ainda que em tempos dramáticos muito distantes, o Sócrates platônico encontra-se com representantes da escola de Eleia. No primeiro deles, o ainda bastante jovem Sócrates tem um encontro com o núcleo duro, por assim dizer, de tal escola filosófica, isto é, o seu fundador Parmênides e o seu mais próximo e famoso discípulo, Zenão de Eleia - aliás, o próprio texto do diálogo nos informa que o último fora o "favorito" (paidiká) do primeiro (Prm. 127b-c). Assim, logo no começo do diálogo (Prm. 128a-b), em função da leitura de um livro de Zenão (feita pelo próprio autor), Sócrates traz à baila a tese filosófica central do eleatismo, que ele atribui à autoria de Parmênides: “o todo é um” (hèn [...] eînai tò pân). E essa tese fora alcançada, por Sócrates, indiretamente, a partir de um paradoxo recém exposto por Zenão (Prm. 127e): a "impossibilidade de o múltiplo ser" (adýnaton [...] pollà eînai). Já no Sofista, o velho Sócrates, quando está sendo processado, encontra-se com um Estrangeiro de Eleia, o qual fará o papel de verdadeiro crítico do eleatismo, chegando mesmo a valer-se da imagem do "parricídio” (patraloías - Sph. 241d) contra Parmênides. De um lado, pois, no primeiro diálogo, o Parmênides, encontramos Platão criticando a si mesmo, ao submeter sua hipótese das Ideias a tão rigoroso teste (Prm. 127a-135c). De outro lado, no segundo diálogo, o Sofista, vemos nosso Filósofo pondo em cena a crítica final do eleatismo também no quadro de uma autocrítica (eleática, nesse caso), posta na boca do Estrangeiro de Eleia. Em ambos os casos, muito provavelmente, parece mesmo tratar-se de um acerto de contas entre as ontologias platônica e eleática - ou, simplesmente, entre o platonismo e o eleatismo.
} 
dessemelhantes serem semelhantes e as semelhantes, dessemelhantes, é também impossível haver múltiplas coisas [adýnaton [...] pollà eînai], não é? Pois, se houvesse múltiplas coisas, seriam afetadas pelo que é impossível [Portanto, não há múltiplas coisas] (Prm. 127e; interpolações minhas)².

Da releitura dessa hipótese zenoniana, na sequência imediata do diálogo (Prm. 127e128e), Sócrates deduz que Zenão está dizendo o mesmo que seu mestre Parmênides, apenas que o discípulo afirma "não haver múltiplas coisas" (ouk ésti pollá), enquanto o mestre afirmara em seu poema "o todo ser um" (hèn eînai tò pân). Zenão não nega essa interpretação de Sócrates, ao contrário, a confirma, embora esclareça que escrevera o tal livro na juventude, e que sua hipótese fora motivada por espírito juvenil de controvérsia contra aqueles que acusavam as consequências ridículas da tese parmenídica (i.e., de que o "um é [real]" - hén esti), devolvendo-lhes na mesma moeda e mostrando que o contrário daquela tese (ou seja, de que o "múltiplo é [real]" - pollá estin) implica consequências igualmente ridículas. Portanto, afirma o discípulo Zenão: sim, seus argumentos visam prestar auxílio à principal tese filosófica de seu mestre Parmênides, a saber, aquela que, de forma absoluta e sobre os aspectos lógico e ontológico, indiscernivelmente, de um lado afirma a necessidade do um (hén esti) e de outro nega a possibilidade do múltiplo (ouk ésti pollá).

Desse modo, a prova zenoniana da hipótese parmenídica é construída ex negativamente, isto é, uma vez demonstrados os absurdos implicados na hipótese da "existência da multiplicidade" (pollá estin), pretende-se que automaticamente esteja validada, lógica e ontologicamente, de modo indiscernível (no que diz respeito à lógica e à ontologia), a hipótese exatamente contrária, ou seja, a parmenídica, aquela que afirma a "existência do um" (hén esti). Trata-se de um argumento que se estrutura na forma de modus tollens ${ }^{3}$, como segue: (1) se há multiplicidade [M], então há contradição $[\mathrm{C}]$ na realidade; (2) ora, não pode haver contradição $[\sim C]$ na realidade (não é racional concebê-la); (3) logo, não há multiplicidade $[\sim M]$. Formalmente, então, temos: $M \rightarrow C, \sim C \vdash \sim M^{4}$. A forma lógica desse paradoxo zenoniano, como comumente é chamado, é válida, apesar da obscuridade de todo o argumento ${ }^{5}$; trata-se de uma prova por reductio ad absurdum. E ainda que, especialmente

\footnotetext{
${ }^{2}$ Sigo e cito - aqui e em todas as ocorrências de citações diretas do texto do Parmênides nesse artigo - a tradução, para o português do Brasil, de Maura Iglésias e Fernando Rodrigues do Parmênides. Nessa citação acima (Prm. 127e), a última frase, entre colchetes, é acréscimo meu, a título de deixar explícita a conclusão lógica do paradoxal argumento zenoniano.

${ }^{3}$ Ao afirmar a estrutura formal do argumento zenoniano por modus tollens, sigo: ALLEN, Plato's Parmenides, p. 76.

${ }^{4}$ Como bem aponta Allen (idem, p. 76) a forma lógica do argumento zenoniano, embora obscura, é válida e se expressa em modus tollens: $\mathrm{M} \rightarrow \mathrm{C}, \sim \mathrm{C} \vdash \sim \mathrm{M}$. Nessa formalização, "M" [multiplicidade] e "C" [contradição] são letras que representam os enunciados, o sinal " $\rightarrow$ " é o símbolo do condicional e o sinal " tem-se a conclusão do argumento; assim, do condicional e da negação de seu enunciado consequente, que são premissas do argumento, tem-se, como conclusão, a negação do enunciado antecedente do condicional. Em outros termos, trata-se de um argumento que funciona por meio de uma prova lógica de reductio ad absurdum. 5 Allen (idem, p. 76) julga o argumento "obscuro" (unclear) e "elíptico" (elliptical), e aponta para a sua "aparência sofística": "Zeno's hypothesis is a paradox. If things which are, are many, it follows that the same things must be both like and unlike. This is impossible; like things cannot be unlike, nor unlike things, like. Therefore, there cannot be many things: plurality is impossible. In logical structure, this paradox is valid; the form is modus tollens. Its sense, however, is extremely unclear. It is not explained why plurality must imply that the same things are both like and unlike; nor is it explained why, granted that this is true, such qualification is to be regarded as absurd. The argument is elliptical and appears to be a mere sophism" (Grifos do autor). Considero que Allen exagera um pouco no seu julgamento do argumento zenoniano. Tal argumento, ainda que paradoxal, sobretudo devido à sua indistinção pressuposta entre lógica e ontologia, torna-se razoavelmente claro quando reconhecemos nele o uso negativo de um princípio de não-contradição (avant la lettre), de um lado, e a própria indistinção entre as premissas lógicas e suas consequências ontológicas que o
} 
para a nossa mentalidade hodierna, seja custoso aceitar que de uma prova formal lógica extraiam-se consequências ontológicas, é exatamente isso que vemos acontecer na construção desse argumento de Zenão: da impossibilidade lógica da contradição pretende-se extrair a impossibilidade ontológica de a multiplicidade ser real.

Nesse sentido, Zenão parece estar pressupondo uma espécie de pré-formulação do princípio de não-contradição, nos seguintes termos (Prm. 127e): o fato de admitirmos logicamente a multiplicidade - que parece ser caracterizada como meramente aparente, sob um ponto de vista eleático - implicará que as coisas (tà ónta) sejam semelhantes (hómoia) e dessemelhantes (anómoia); mas isso é impossível (adýnaton), pois não podem nem os semelhantes serem dessemelhantes (tà hómoia anómoia), nem os dessemelhantes serem semelhantes (tà anómoia hómoia). Eis aí exposta a contradição, que inicialmente parece revelar-se nos próprios termos: o semelhante [S] associa-se ao seu exato contrário, isto é, o dessemelhante - que é igual ao não-semelhante [ $[\mathrm{S}]$. Configura-se assim a contradição formal: o semelhante é não-semelhante $[S \wedge \sim S]$. E o mesmo ocorre quando supomos a associação do dessemelhante [D] ao semelhante, que por sua vez é igual ao nãodessemelhante $[\sim D]$, isto é, instaura-se a contradição formal: o dessemelhante é nãodessemelhante $[\mathrm{D} \wedge \sim \mathrm{D}]$.

Embora Sócrates, nessa altura do diálogo (Prm. 127e-128b), ao reconstruir os termos do argumento zenoniano, não mencione a palavra grega enantía (coisas contrárias ou contraditórias), ela aparece logo a seguir, na boca do próprio Zenão (Prm. 128d), que afirma pretender demonstrar que a hipótese adversária àquela de Parmênides implica tantas "coisas ridículas" (geloîa) e "coisas contrárias" (enantía) a ela mesma quanto os adversários do mestre à hipótese dele objetam. Esta é, de fato, a primeira vez que uma palavra - enantía associada às noções de contrariedade e de contradição aparece no texto do Parmênides. O que quero argumentar é que seu emprego, aqui, e doravante na exposição socrática da hipótese das Ideias, estabelece a arena teórica em que o eleatismo e o platonismo medem forças no diálogo Parmênides, a saber: trata-se do problema da contradição lógica e suas consequências ontológicas para a construção do discurso filosófico que pretenda descrever a estrutura da realidade.

\section{IV}

Na sequência do diálogo (Prm. 128e-130a), a hipótese das Ideias é exposta por Sócrates exatamente como dissolução do paradoxo zenoniano reconstruído acima; ele a expõe nos seguintes termos: inicialmente, trata-se de uma distinção teórica (que parece ser, a um só tempo, lógica e ontológica) entre, de um lado, a Ideia ou Forma em si e por si mesma (autò kath' hautò eîdós - 129a) e, de outro, as muitas coisas dela participantes (metalambánonta). Seguindo esse esquema teórico, na continuidade da exposição de Sócrates, de um lado há a Semelhança (homoiótêtos) em si e por si mesma, bem como seu contrário e contraditório (enantíon), a Dessemelhança (anómoion) em si e por si mesma; de outro lado, estão as coisas múltiplas (pollá) que delas são participantes, e que exatamente em função dessa participação (metalambánein) exibem entre si semelhanças e dessemelhanças, podendo ser descritas

compõem, de outro. Ao final das contas, é a negação da possibilidade da contradição - formal, sob o ponto de vista lógico - na realidade que garante a própria validade lógica do argumento, bem como as aplicações de suas consequências para uma ontologia (eleática). No fundo, o que nos incomoda (i.e., a nossa mentalidade moderna), parece-me, é o salto entre as esferas lógica e ontológica - em metáfora, um característico pulo de gato, ou, pior ainda, um passe de mágica - e não a forma lógica do argumento como um todo. 
nesses mesmos termos - i.e., de serem semelhantes e dessemelhantes ${ }^{6}$. Sócrates aponta para si mesmo, para Zenão (a quem se dirige diretamente) e para as "outras coisas chamadas múltiplas" (pollá) ${ }^{7}$ como exemplos de tais participantes das Ideias. Um pouco mais adiante (Prm. 129c-d), ao retomar a si mesmo como exemplo, Sócrates explicita o caráter múltiplo de tais coisas: trata-se de terem elas múltiplos e distintos aspectos, como ele mesmo (Sócrates) tem um lado direito e um lado esquerdo, uma parte da frente e uma parte de trás, uma parte posterior e uma parte inferior; enfim, Sócrates é "um” (hén) em relação aos outros (homens) ali presentes, mas é "múltiplo" (pollá) - isto é, de muitos aspectos distinguíveis - em relação a si mesmo.

Essa caracterização das coisas múltiplas revela-se importante na medida em que, desde elas e em contraste com elas, emerge a natureza das próprias Ideias, das quais aquelas são participantes. Enquanto as coisas múltiplas - tais como nós mesmos - apresentam muitos e distinguíveis aspectos, as Ideias, por sua vez, são pura "unidade" (henós). Em síntese, o esquema teórico da hipótese das Ideias, tal como exposta pelo jovem Sócrates nesse início do Parmênides, configura-se assim: há muitas coisas (de múltiplos aspectos) que participam de uma Ideia (de um único aspecto). Trata-se da reiterada fórmula básica da

\footnotetext{
${ }^{6}$ Aqui há a questão sobre o que, exatamente, seriam a semelhança e a dessemelhança presentes nas coisas participantes das respectivas Ideias da Semelhança em si e da Dessemelhança em si. Platão, nessa passagem do Parmênides, parece descrever a semelhança e a dessemelhança presentes nas coisas participantes das Ideias como se fossem características (propriedades) presentes nas próprias coisas - no mesmo sentido que uma coisa que participa da Ideia da Brancura em si torna-se branca, isto é, tem presente em si, como uma característica ou propriedade sua, a brancura (dito em outros termos, trata-se de uma "coisa branca"). Essa descrição pode soar estranha aos nossos ouvidos, dada nossa mentalidade moderna, já que tendemos a pensar que semelhança e dessemelhança não são características (propriedades) das próprias coisas, tal como a brancura (ser branco), mas são caracterizações que fazemos discursivamente apenas quando comparamos diferentes coisas. Ou seja, semelhança e dessemelhança, nesse sentido, não são propriedades das coisas, mas relações que nós estabelecemos discursiva e comparativamente entre elas, ao relacionarmos umas com as outras. Nesse caso, semelhança e dessemelhança não estariam nas coisas, como propriedades suas, mas em nossos juízos sobre as coisas entre si (na exata medida que são comparadas por nós). Em síntese, trata-se de diferentes usos do discurso quando descrevemos as características próprias de uma coisa (v.g.: "A é branco") e quando relacionamos duas ou mais coisas, qualificando-as como semelhantes ou dessemelhantes (v.g.: "A1 e A2 são semelhantes"; "A e B são dessemelhantes"). Obviamente, isso não elimina a questão sobre a presença de características ou propriedades objetivas, presumivelmente existentes nas próprias coisas, que nos permitam declará-las semelhantes ou dessemelhantes. De todo o modo, esse problema, que salta aos nossos olhos, não é tratado no Parmênides; a hipótese exposta pelo jovem Sócrates simplesmente não chega a esse nível de detalhamento - ainda que possamos entrever que são exatamente esses problemas que estão por trás da hipótese das Ideias exposta pelo jovem. Por mais estranho que nos pareça, a semelhança e a dessemelhança presentes nas coisas (que são participantes dessas respectivas Ideias) são tratadas por Sócrates como se fossem características próprias (propriedades) das coisas, no mesmo sentido que "uma coisa é branca". Em um outro sentido, contudo, desde a perspectiva da hipótese platônica das Ideias, duas coisas só podem ser ditas semelhantes, por serem realmente semelhantes, nos seguintes termos: a1 e a2 são semelhantes entre si por participarem da mesma Ideia de A. O problema é que Sócrates, nessa passagem do Parmênides (128e-13oa), está supondo que essa Ideia de A seja a Semelhança em si e por si, e não a Ideia de A em si mesma. Num exemplo material, no caso de tratar-se de homens particulares semelhantes entre si, seriam eles semelhantes pela sua participação na Ideia de Semelhança, e não na Ideia de Humanidade em si e por si - nesse último caso, gerarse-ia um outro raciocínio, a saber, dois homens (h1 e h2) são semelhantes entre si por serem participantes da mesma Ideia de Humanidade ( $\mathrm{H}$ em si e por si mesma), no sentido de pertencerem a um mesmo gênero ou espécie de coisas, sendo a humanidade uma propriedade distintiva e característica dessas coisas. Em diferentes passagens do Parmênides, e mesmo em diferentes diálogos platônicos, esses dois raciocínios, aparentemente incoerentes entre si, compõem a hipótese das Ideias, sem estabelecer uma regularidade na ordem da argumentação ou das razões. Enfim, tais questões compõem problemáticas para a interpretação e a compreensão dessa famosa hipótese platônica.

${ }^{7}$ Parmênides, 129a: "E que, nestas duas coisas [dyoîn óntoin], que são, tanto eu quanto tu, quanto as outras coisas que chamamos múltiplas [pollà kaloûmen], temos participação [metalambánein]?"
} 
estrutura da hipótese platônica das Ideias $^{8}$, a saber: há muitas coisas múltiplas em relação a uma Ideia única - e tal fórmula será literalmente enunciada logo adiante no texto do Parmênides (131b9), para descrever a estrutura desejável da relação de proporção entre Ideia e seus participantes, nos seguintes termos: "hèn epi polloîs" (um para muitos).

Todas as questões (potenciais objeções) do velho Eleata, dirigidas ao jovem Sócrates, na sequência do diálogo, as quais refletem pontos críticos (i.e., de possível fragilidade) da própria teoria, dependem de uma certa compreensão dessa estrutura fundamental - hèn epi polloîs - da hipótese das Ideias; são elas: (a) sobre a extensão das Ideias; (b) sobre os problemas da participação; (c) as diferentes formulações do argumento do regressus ad infinitum; (d) sobre a natureza das Ideias; (e) sobre a separação entre Ideias e coisas e a possibilidade da (in)cognoscibilidade das primeiras.

Antes de avançarmos em tais questões críticas sobre a teoria das Ideias, a partir das respectivas perguntas a ela objetadas por Parmênides, há que se registrar que a hipótese exposta por Sócrates desativa o paradoxo zenoniano através da enunciação positiva do princípio de não-contradição, que opera no interior da mesma hipótese lógico-ontológica das Ideias. Em síntese, dado o simples fato de haver multiplicidade, não haverá contradição na realidade, já que as coisas múltiplas (que assim o são em função de seus muitos e distintos aspectos) apenas são afetadas e exibem diferentes características, em diferentes aspectos e, podemos supor, por possibilidade óbvia, em diferentes tempos, devido à sua participação nas Ideias. Já essas últimas (as Ideias), por sua vez, são as características puras, postuladas como realidades em si mesmas (i.e., ontologicamente consistentes, de realidade própria, e distintas das coisas que delas participam). Nesse sentido, afirma Sócrates, "não é espantoso" (oudé ti thaumastòn - Prm. 129d5) que uma coisa múltipla (de múltiplos aspectos) seja semelhante e dessemelhante ao mesmo tempo, ou uma e múltipla, ou grande e pequena, ou esteja em movimento e em repouso, já que estas são características distintas que a afetam, que a qualificam (ontologicamente), em função de sua participação nas Ideias (em si e por si mesmas) respectivas a tais características, a saber: a Semelhança (homoiótêta), a Dessemelhança (anomoiótêta), a Unidade (tò hèn), a Quantidade (plệthos), o Movimento (kínesin) e o Repouso (stásin - Prm. 129d-e). Não há contradição no fato de que coisas múltiplas, de diferentes aspectos e imersas no tempo (i.e., no devir do mundo físico - pois os exemplos de Sócrates são de "paus" [xýla] e "pedras" [líthous] - Prm. 129d), sejam afetadas e exibam diferentes características, até mesmo contraditórias entre si, desde que em diferentes aspectos ou tempos. Haveria contradição, e por isso seria espantoso, se as próprias Ideias, contrárias ou contraditórias entre si, misturassem-se, participassem-se umas das outras, já que elas não são coisas múltiplas, mas puras unidades de significação, puras características $^{9}$, abstraídas, distinguidas (ou separadas), postuladas como realidades

\footnotetext{
${ }^{8}$ Essa é uma fórmula que aparece repetidamente em várias passagens textuais platônicas da República, por exemplo: 475e-476a; 490a-b; 493-494a; 507a-c; 596a-b.

${ }^{9} \mathrm{O}$ potencial de contradição, apontado por Sócrates nessa passagem do Parmênides (129d-e), diz respeito exclusivamente à impossibilidade de Ideias completamente contrárias ou contraditórias, tais como Semelhança (homoiótéta) e Dessemelhança (anomoiótẹta), participarem-se (ou misturarem-se) mutuamente. Ora, tal contradição ficaria evidente na exata medida que tais Ideias são as características puras e as próprias significações, reificadas, da semelhança e da dessemelhança; nelas não há qualquer outro aspecto (ontológico) ou significado (lógico) - nesse sentido, a Ideia é postulada como pura unidade. Desse modo, cogitar-se que a "Semelhança em si e por si mesma" possa participar (misturar-se) da "Dessemelhança em si e por si mesma" é tão contraditório quanto afirmar que o significado de semelhante é também o significado de dessemelhante, ou que "o quadrado é redondo" - nesse sentido, tal enunciado, que afirmaria que "a Semelhança participa (i.e., identifica-se com) da Dessemelhança”, funcionaria como uma espécie de contradição nos termos (ainda que as Ideias não sejam apenas termos de significação, mas realidades, com consistência ontológica e distintas das coisas). Além disso, a presumida aplicação de um mecanismo de não-contradição nos termos para impedir a
} 
independentes das coisas delas participantes e de consistência ontológica própria (i.e., distinta daquela das coisas múltiplas, tais como paus, pedras e homens).

Isso parece ser suficiente para demonstrar que a hipótese das Ideias exposta pelo jovem Sócrates, no Parmênides, visa combater e desativar o paradoxo zenoniano - e nesse sentido ela se contrapõe a uma versão do eleatismo, isto é, aquela de Zenão. A simples presença de Parmênides e de seu discípulo predileto, na cena do diálogo, parece avalizar a interpretação de que, aos olhos de Platão, o que está em questão também é um combate ao eleatismo. Dito de outro modo, desde fora do diálogo, parece ser um acerto de contas entre o platonismo e o eleatismo. E tal acerto de contas se dá através da questão da contradição, nas disputas entre ambas essas filosofias sobre como compreendê-la (i.e., a própria contradição), sobre como lidar com ela, tanto na construção de uma lógica quanto de uma ontologia, ao tratar das difíceis relações entre um (hén) e múltiplo (pollá). Nesse sentido, sugeri que a exposição da hipótese das Ideias no Parmênides, em seu embate com o eleatismo, é motivada por uma questão puramente teórica, a saber, a da (não)contradição, da qual dependem quaisquer lógica e ontologia que componham o discurso filosófico coerentemente.

Como já era de se esperar, a partir daquela exposição da hipótese teórica das Ideias feita pelo jovem Sócrates, no diálogo, as atenções - tanto as de Parmênides quanto as nossas - se voltam para as seguintes questões: (1) quais Ideias (que tipo ou espécie de Ideias) realmente existem? (2) qual a sua consistência ontológica (ou sua natureza)? (3) em que sentido elas se distinguem ou se separam das coisas? (4) o que são as relações de participação entre Ideias e coisas? (5) podem as Ideias ser conhecidas e provadas? Essas parecem ser as questões fundamentais que estão por detrás das aparentes objeções feitas por Parmênides à hipótese antes exposta por Sócrates. Digo aparentes objeções porque, na dinâmica dramática do diálogo, o Eleata apenas faz perguntas, apresenta questões e problemas; ao que parece, é Sócrates quem as toma como objeções fatais à sua hipótese, na medida em que não consegue responde-las de forma a neutralizar seus efeitos aporéticos sobre a possibilidade lógico-ontológica das Ideias.

O que pretendo mostrar, a seguir, é que a forma como Parmênides constrói as suas questões - ainda que eu não possa examiná-las todas, em particular e detalhadamente, agora - determina uma certa compreensão da hipótese das Ideias, imediatamente assumida por Sócrates, no interior da qual emergem certas respostas para aquelas cinco perguntas suscitadas acima. Paralela e concomitantemente, quero argumentar que existe sempre a possibilidade de uma leitura distinta daquela que é assumida por Sócrates ao lidar com as questões de Parmênides e, portanto, também há respostas alternativas possíveis àquelas

participação mútua entre Ideias contrárias ou contraditórias acentua o caráter inegavelmente lógico da hipótese das Ideias; nessa, a rigor, lógica e ontologia jamais se separam - são duas faces da mesma moeda. Por fim, parece-me que Sócrates, aqui, não está tratando do mesmo problema que será tratado no diálogo platônico Sofista - apesar de citar Movimento (kínesis) e Repouso (stásis), que são Ideias centrais na construção teórica de tal diálogo (Sofista) - onde o tema da possibilidade da participação mútua entre Ideias (ou "Gêneros" [géne], como lá são chamadas) é o foco da discussão. No Sofista, a questão central é garantir a possibilidade da diversidade entre as Ideias, e por decorrência a Diversidade ou Alteridade (héteros) como um princípio da estrutura fundamental da própria realidade - ainda que para isso, também no Sofista, o princípio de não-contradição seja a pedra-de-toque (ou o ponto de apoio) no combate ao eleatismo. Diferentemente disso, aqui no Parmênides (129d-e), a questão é assegurar o caráter unitário das Ideias, quando contrastadas às coisas múltiplas delas participantes, e nesse sentido escapar da contradição presente no paradoxo zenoniano. 
mesmas perguntas apontadas no parágrafo anterior. Esse procedimento, contudo, não deve nos impedir de reconhecer quando as questões do Eleata nos impulsionam, em sua própria direção implicitamente apontada, a conclusões e argumentos corretos.

Já de início, em sua primeira intervenção no diálogo (Prm. 130a-b), Parmênides pergunta a Sócrates:

Mas, dize-me: tu mesmo assim fizeste a divisão [diéirẹsai] tal como falas: de um lado certas formas [Ideias] mesmas [choris mèn eíde autà átta], de outro as coisas que delas participam [choris dè tà toúton aû metéchonta]? E te parece a semelhança mesma ser algo [eînai autè homoiótẹs], separada [choris] da semelhança que temos [hẹmeîs homoiótẹtos échomen], e também o um [hèn] e as múltiplas coisas [pollà] e todas as coisas que há pouco ouviste de Zenão? (Grifos dos tradutores. Interpolações minhas)

Em resposta, Sócrates admite a distinção (diéiressai) por ele feita entre Ideias (eíde $)$ e coisas delas participantes (metéchonta). Contudo, o que impressiona, nessa breve passagem, é o uso repetitivo, por Parmênides, da palavra (um advérbio) "chorís": ele a emprega três vezes, como podemos ver no texto acima. Note-se bem: a pergunta do Eleata não se restringe a (re)afirmar a "distinção" (diéiresai) entre Ideias e seus participantes, mas insistentemente induz o jovem Sócrates a aquiescer a "separação" (chorís) entre Ideias e coisas delas participantes, ao afirmar, de forma incisiva, primeiro, de um lado as "chorís eíde autà" (Ideias mesmas separadas), de outro as "choris metéchonta" (coisas participantes separadas); depois, de um lado a "autè homoiótés choris" (semelhança mesma separada), de outro a "hemeîs homoiótẹtos échomen" (semelhança que nós temos). Em síntese, as perguntas de Parmênides argutamente empurram Sócrates a admitir que a "distinção" (diéiresai) entre Ideias e coisas delas participantes é equivalente à "separação" (chorís) entre elas, e o Jovem o faz de forma completamente inadvertida, sem oferecer qualquer resistência ao grande Eleata - o qual continuará utilizando a palavra "chorís" insistente e repetidamente para se referir à (distinção) separação entre Ideias e seus participantes na sequência imediata do texto do Parmênides (v.g.: 130c1; 130d1; 131b1).

Em nenhum momento do diálogo, nem no que vimos até aqui nem no porvir da discussão, Sócrates e Parmênides examinam, franca e abertamente, o que significa a distinção (diéirésai) e a separação (chorís) agora afirmadas entre as Ideias e os seus participantes. Exatamente essa lacuna no exame da questão, que permanecerá maupreenchida pela simples aquiescência de Sócrates à sugestão parmenídica da separação (chorís) entre Ideias e coisas, é determinante para o desenvolvimento do diálogo. E justamente aqui está o principal ponto de apoio dos argumentos que apresento em prol de minha interpretação: o fato de que a "distinção" (diéirésai) e a "separação" (chorís) entre Ideias e coisas não são conceitualmente esclarecidas e firmadas, nem em si mesmas nem em relação uma à outra, em nenhum momento do diálogo entre Parmênides e Sócrates, leva a todas as aporias posteriores objetadas à hipótese das Ideias, a saber: as dificuldades de se pensar a participação; as duas possibilidades de regressus ad infinitum nas Ideias; por fim, a possibilidade da completa separação ontológica entre Ideias e coisas múltiplas (configurando-se duas esferas de realidades completamente distintas) e da incognoscibilidade das próprias Ideias. Em resumo, o fato de Sócrates não esclarecer, em termos conceituais claros, o que são as Ideias (qual sua natureza, sua condição ou estatuto ontológico) e como elas se distinguem ou se separam das coisas - e nem ser exigido, pela parte de Parmênides, a prestar tais esclarecimentos - permitirá que o velho Eleata imediatamente comece a tratar das Ideias "como se fossem coisas" (objetos comuns de percepção), e como se existissem segundo o mesmo estatuto ontológico dessas. Dito de 
forma direta: maliciosa ou equivocadamente, Parmênides atribui às Ideias o mesmo status das coisas.

Naturalmente, se as Ideias existem como se fossem coisas, apenas que de uma única característica (sob os pontos de vista lógico e ontológico), a distinção (ou separação) entre elas e as coisas é a mesma que existe entre dois objetos (ou coisas) quaisquer de nossa experiência comum (v.g., duas pedras, ou uma pedra e um pau), e as dificuldades de se conceber a participação entre Ideias e coisas serão do mesmo nível que seriam se quiséssemos falar que "uma pedra participa de outra". E ainda que, sobre o ponto de vista do personagem Parmênides, não possamos determinar se essa forma de tratar as Ideias - haja vista a exiguidade da exposição de Sócrates sobre a própria natureza das mesmas - é motivada por malícia ou por equívoco (ou desinformação), penso que não é exagero cogitarmos (e até mesmo afirmarmos) que, acerca do ponto de vista do autor Platão, tal tratamento das Ideias, através do mesmo personagem (Parmênides), é proposital, de forma a nos advertir nos seguintes termos: se tratarmos as Ideias como se fossem coisas (objetos de nossa experiência comum), então cairemos em todas as aporias nas quais Sócrates se vê enredado a seguir, no desenrolar do diálogo.

Podemos ver isso facilmente no próprio texto do Parmênides. Os efeitos da suposição não-discutida da separação (chorís) entre Ideia e coisas dela participantes se mostram logo adiante, na construção da primeira aporia da participação (Prm. 13oe-131d), quando Parmênides induz Sócrates, inicialmente, a aquiescer a tese de que "[...] cada uma das coisas que têm participação ou bem têm participação na forma inteira, ou bem em uma parte dela" (hólou toû eídous è mérous hékaston tò metalambánon metalambánei - Prm. 131a). Disso, o Eleata deduz que a Ideia, sendo uma, inteira e a mesma, não poderá estar em cada uma das coisas múltiplas separadas, sob pena de estar ela mesma (i.e., a Ideia) separada de si mesma $^{10}$. Portanto, nessa forma de conceber-se a participação (metálepsis - Prm. 131a5), isto é, como alguma espécie de presença da Ideia una nas coisas múltiplas separadas, a própria participação é teoricamente inviabilizada (tanto de um ponto de vista lógico quanto ontológico). Desse modo, a primeira possibilidade de conceber-se a participação entre Ideia una e coisas múltiplas, enunciada acima naquela disjunção (ou as coisas participam do todo ou de parte da Ideia), é impossibilitada: não é possível à Ideia una (sem perder seu caráter de exclusiva unidade - não em termos de significação lógica, mas como se fosse uma coisa) estar em cada coisa múltipla dela participante; e essa conclusão é alcançada, por Parmênides, ainda que, nessa altura do diálogo, também não se avance no que realmente significa a participação entendida como "[...] a Ideia que é una e inteira estar [presente] em cada uma das coisas múltiplas [...]” (hólon tò eîdos en hekástọi eînai tôn pollôn hèn ón - Prm. 131a), e muito menos sobre o que esse entendimento acarretaria para a compreensão da natureza (ou estatuto ontológico) das próprias Ideias.

Na sequência do diálogo, diante da alternativa sugerida por Sócrates (Prm. 131b), de que as Ideias, como o "dia" (hêméra), poderiam estar presentes em muitos lugares sem perder sua unidade, analogia esta que é solenemente ignorada por Parmênides, este último imediatamente a substitui pela imagem da "[...] vela (histíon) [de navio] que cobre muitos homens [...]”, como se fosse possível “[...] ser o um inteiro sobre os muitos” (hèn epì polloîs

\footnotetext{
10 “[Parm.] Então, parece-te que a forma inteira [hólon tò eîdos], sendo uma [hèn ón], está em cada uma das múltiplas coisas [en hekástói eînai tộn pollônn]? Ou como seria?

[Sóc.] Mas que impede, Parmênides, disse Sócrates, <que ela seja>?

[Parm.] Então, sendo uma e a mesma [hèn ... òn kaì tautòn], estará, inteira [hólon], simultaneamente, em coisas que são múltiplas e separadas [en polloîs kaì chorìs], e, assim, ela estaria separada de si mesma [autò hautoû chorìs]." (Prm. 131a-b. Grifos e acréscimos dos tradutores).
} 
eînai hólon $)^{11}$. Pois bem, eis as consequências absurdas que o Eleata extrai dessa fórmula na sequência imediata do diálogo (Prm. 131C-e), a saber: as coisas participariam apenas de parte da Ideia - já que a fórmula do "hèn epi pollô̂s" (um para muitos) fora metaforizada na imagem da "vela de navio", como se a Ideia fosse uma vela (ou um grande pano, ou uma lona de circo) que cobre cada uma das coisas que dela participam. Assim, cada uma das coisas participará apenas de uma parte da Ideia, exatamente daquela parte que a cobre (Prm. 131c). Disso, extraem-se duas consequências igualmente absurdas e inaceitáveis: a divisibilidade da Ideia (que, assim, deixa de ser exclusivamente una), de um lado, e a impossibilidade da participação das coisas na totalidade da Ideia, de outro ${ }^{12}$.

Aplicando-se a casos específicos, essa compreensão do que seja a própria Ideia - i.e., uma vela estendida sobre as muitas coisas múltiplas dela participantes - leva a absurdos lógico-ontológicos igualmente inaceitáveis, como segue: (i) coisas múltiplas grandes serão grandes por participarem de uma (pequena) parte da Ideia de grandeza (Prm. 131c-d); (ii) coisas múltiplas iguais serão iguais por participarem de parte (que exatamente por ser uma parte menor passa a ser desigual do todo) da Ideia de igualdade - o que equivale a afirmar que uma coisa é igual por participar de parte desigual da Igualdade em si (Prm. 131d); (iii) coisas múltiplas pequenas serão pequenas por participarem de uma parte menor da Ideia de pequenez (e essa última, em relação à parte, é maior, ou seja grande - o que é igual a afirmar que "a Pequenez torna-se grande" em relação a suas partes); além disso, as coisas participantes da Pequenez recebem uma pequena parte do pequeno, pelo acréscimo do qual tornam-se ainda menores - e não maiores, como seria de se esperar que se tornasse (maior) qualquer coisa à qual se acresça algo (Prm. 13ıd-e).

Nessa rápida visada sobre tais consequências absurdas extraídas da imagem de Parmênides, de que a Ideia seja uma espécie de vela de navio estendida sobre as coisas dela participantes, sugestão através da qual ele induz Sócrates a uma compreensão muito peculiar e favorável aos seus próprios interesses da relação estrutural entre Ideia una e coisas múltiplas, expressa na fórmula do "hèn epi polloîs", ficam evidentes duas características indeléveis presentes na compreensão da hipótese das Ideias expressa pelo Eleata, a saber: primeiro, que a Ideia é tratada como se fosse uma coisa, um objeto qualquer da nossa experiência comum do mundo, tal como o percebemos sensivelmente. Nesse sentido, a

\footnotetext{
${ }^{11}$ “[Sóc.] Não estaria, disse ele, se, pelo menos, como o dia [hẹméra], <que>, sendo um e o mesmo, está em muitos lugares simultaneamente e nem por isso está ele mesmo separado de si mesmo [mía kaì hẹ autè oûsa pollachoû háma estì kaì oudén ti mâllon autè hautệs chorís estin], se assim também cada uma das formas fosse uma e a mesma, <estando> simultaneamente em todas as coisas [ei hoúto kai hékaston tôn eidôn hèn en pâsin háma tautòn eíe].

[Parm.] De bela maneira, Sócrates, disse ele, fazes uma e a mesma coisa <estar> simultaneamente em muitos lugares [hèn tautòn háma pollachoû poieîs], como se, cobrindo com uma vela muitos homens [hoîon ei histío $i$ katapetásas polloùs anthrópous], dissesses ser ela, inteira, uma sobre múltiplos [hèn epì polloîs eînai hólon]. Ou não é algo desse tipo que acreditas estar dizendo?

[Sóc.] Talvez, disse ele." (Prm. 13ıb. Grifos e acréscimos dos tradutores).

12 "[Parm.] Será então que a vela inteira estaria sobre cada um [hólon ... hekástôi tò histíon eíe án], ou uma parte dela sobre um [è méros autoû], outra sobre outro [állo ep'álloi]?

[Sóc.] Uma parte [Méros].

[Parm.] Logo, Sócrates, disse ele, são divisíveis as formas mesmas [Meristà ... éstin autà tà eídẹ], e as coisas que delas participam participariam de uma de suas partes [kai tà metéchonta autôn mérous àn metéchoi], e não é mais o todo que estaria em cada uma das coisas [kai oukéti en hekástoi hólon], mas, sim, uma parte caberia a cada coisa [allà méros hekástou àn eíe ].

[Sóc.] Parece pelo menos que é assim.

[Parm.] Será então, Sócrates, que estarás disposto a dizer que a forma, uma [tò hèn ê̂dos], em verdade, se nos divide e ainda será uma [hêmîn ... merízesthai, kai éti hèn éstai]?

[Sóc.] De maneira alguma, disse Sócrates." (Prm. 131c. Grifos dos tradutores).
} 
espacialidade e a divisibilidade pressupostas à Ideia, presentes na imagem da "vela estendida sobre as muitas coisas", que condicionam as relações de participação entre a Ideia e seus participantes (na medida em que uma coisa só participa da exata parte da "Ideia-vela" que a cobre), é indício flagrante e inegável de que Parmênides trata das Ideias "como se fossem coisas". Trata-se de uma característica muito peculiar da leitura do Eleata sobre a hipótese das Ideias de Sócrates, mas que resulta em uma compreensão distorcida dessa última e que acaba por inviabilizá-la teoricamente. Nesse sentido preciso, trata-se de uma leitura antiplatônica, essa do velho Parmênides, pois nega o elemento essencial do platonismo aqui, qual seja: a distinção ontológica - mas que não implica completa separação (chorís) - entre Ideias unas e coisas múltiplas.

Em segundo lugar, agora sob um ponto de vista predominantemente lógico, as contradições apontadas pelo Eleata ( $v . g .:$ coisas grandes que o são por participarem de uma parte pequena da Grandeza em si; ou, uma coisa que é igual por participar de parte desigual da Igualdade em si), que ao fim e ao cabo configuram-se como contradições nos termos, evidenciam como a hipótese das Ideias também é resultante da lida de Platão com o problema da contradição - e nessa perspectiva, podemos ver aqui, nessa passagem do Parmênides (131c-e), novamente, um eco do embate entre platonismo e eleatismo em torno desse grande problema filosófico, i.e., o da contradição. Para além disso, nesse caso, a abordagem lógica de problemas ontológicos também revela a indistinção teórica entre esses dois planos, o lógico e o ontológico - o que para nós, em nosso próprio tempo, pode ser difícil de compreender e aceitar. De todo modo, ao contrário do aspecto anterior, que levou Parmênides a uma posição anti-platônica, a indistinção entre lógica e ontologia aproxima o eleatismo e o platonismo, revelando-se um traço teórico comum dessas duas grandes filosofias antigas. Não é mero acaso, então, que o acerto de contas entre o eleatismo e o platonismo se dê exatamente nessa arena das relações entre lógica e ontologia, através da questão central da contradição, tomada como pedra-de-toque para a resolução lógica de problemas ontológicos. Podemos ver isso claramente tanto no Parmênides quanto no Sofista, ambos diálogos que encenam tal acerto de contas entre platonismo e eleatismo, ainda que, sempre, desde a perspectiva do primeiro.

Enfim, é essa mesma compreensão das Ideias - como se fossem coisas - que está na base do mecanismo do regressus ad infinitum a elas objetado, em suas duas ocorrências na sequência do Parmênides (131e-132b; 132d-133a) - trata-se de versões do argumento tornado célebre pela alcunha aristotélica de "terceiro homem"13. Note-se bem: por detrás de ambas essas formulações do argumento de regressão infinita objetado à postulação das Ideias está a equiparação entre Ideias e coisas delas participantes, como se ambas essas categorias de entidades tivessem o mesmo estatuto ontológico e pudessem simplesmente ser equiparáveis. Na primeira formulação do argumento do regressus ad infinitum (Prm. 131e-132b), é isso que explica o mecanismo que, diante da visada de um conjunto de coisas grandes, abstraída a característica da grandeza e postulada a Grandeza em si mesma, então, numa segunda visada, que agora abrange coisas grandes e a Grandeza em si, impõe a exigência da postulação de uma segunda Ideia de Grandeza, e assim ad infinitum. Ou então, na segunda formulação do mesmo argumento (Prm. 132d-133a), dado que há um conjunto de coisas semelhantes entre si (v.g.: a1, a2, a3), a semelhança dessas se explica pelo fato de se assemelharem a uma mesma Ideia (v.g.: A em si), na condição de "imagens copiadas" (eikasthênai - Prm. 132d4) dela; ora, a simples equiparação entre coisas semelhantes (a1, a2, a3) foi condição suficiente para postular a Ideia (A em si); agora, a equiparação entre coisas

\footnotetext{
${ }^{13}$ Aristóteles menciona o argumento do "terceiro homem" (ho trítos ánthropos) em diversas passagens de sua obra. A título de exemplo, cito algumas: Metaphysica, A, 9, 99ob17; Z, 13, 1039a2-3; M, 4, 1079a13. Sophistici Elenchi, XXII, 178b37-179a11.
} 
semelhantes e a Ideia em si, dada a semelhança dessa última com as coisas dela participantes (a1, a2, a3 e A em si), outra vez é razão suficiente, afirma Parmênides no diálogo (Prm. 132e-133a), para postular uma segunda Ideia ( $\mathrm{A}^{2} \mathrm{em}$ si), e assim ad infinitum novamente. Fica claro, portanto, que em ambos os casos da formulação do argumento do regressus ad infinitum, no Parmênides, é a equiparação entre Ideias e coisas delas participantes que desencadeia o mecanismo da regressão infinita na postulação de Ideias, como se ambas as classes de entidades em questão (i.e., Ideias e coisas) tivessem o mesmo estatuto ontológico. Em uma expressão, trata-se, inequivocamente, de tratar das Ideias como se fossem coisas comuns da nossa experiência.

Evidentemente, por fim, essa mesma compreensão das Ideias - como se fossem coisas $^{14}$ - está na base daquela que Parmênides considera, dramaticamente no diálogo (Prm. 133a-b), a mais terrível das aporias na qual a hipótese de Sócrates pode estar enredada, a saber: a definitiva separação entre Ideias unas (que "não estão entre nós" - Prm. 133c5) e coisas múltiplas; a consequente incognoscibilidade (ágnosta - Prm. 133c1; 135a5) das próprias Ideias por todos nós, que estamos imersos e encerrados entre as coisas múltiplas, as quais estão definitivamente separadas das Ideias (Prm. 133a-135a).

Aqui, não examinarei os detalhes dessa última aporia. Entretanto, quero registrar um argumento: me parece óbvio que essa última aporia é uma consequência inevitável de todo o tratamento dado por Parmênides à hipótese das Ideias desde o começo do diálogo, no seguinte sentido: uma vez estabelecida (1) a separação (chorís) entre Ideias unas e coisas múltiplas delas participantes; (2) dado o tratamento das Ideias como se fossem coisas [materiais]; (3) exatamente em função de (1) e (2), firmada a improbabilidade de qualquer forma de participação (metálépsis ou metalambánein), seja no todo seja em parte, entre Ideias unas e coisas múltiplas; (4) a conclusão do exame da hipótese das Ideias, conduzido segundo as perguntas explícitas do Eleata, só poderia ser a completa separação entre Ideias unas e coisas múltiplas - dentre essas últimas estamos nós, por isso só a elas temos acesso e a consequente incognoscibilidade das primeiras para nós.

Ora, se minha interpretação do texto está correta, e meus argumentos acima expostos são suficientes, então fica demonstrado que a crítica da hipótese das Ideias, na primeira parte do Parmênides, é completamente dependente de dois pressupostos contidos nas perguntas do velho Eleata, os quais são simples e inadvertidamente aquiescidos pelo jovem Sócrates, a saber: (1) a total separação (chorís) entre Ideias unas e coisas múltiplas delas participantes; (2) o tratamento das Ideias como se fossem coisas. Entretanto, leitores atentos e familiarizados com Platão sabem que ambos esses dois pressupostos não são necessários à hipótese das Ideias, além de serem a ela externos e até mesmo estranhos. Com base nisso, conforme procurei expor acima, a partir de uma leitura a contrapelo da presumível crítica da hipótese das Ideias presente no Parmênides, crítica essa levada à cabo sob a capitania do Eleata através de suas perguntas capciosas, como vimos, ouso afirmar, mesmo que em tom especulativo: parece-me que Platão está, aqui, a combater um certo platonismo - e esse último é o real objeto da crítica platônica, e não a hipótese das Ideias.

\section{Referências}

\section{ALLEN, R.E. Plato’s Parmenides. New Haven/London: Yale Univesity Press, 1997.}

\footnotetext{
${ }^{14}$ Podemos denominar esta compreensão das Ideias de "materialista", no sentido bem preciso e exclusivo de conceber-se as mesmas como se fossem "coisas materiais"; ou ainda, poderíamos também chamar essa mesma compreensão de "reificante" ou "coisificante" das Ideias, já que se trata de toma-las como se fossem coisas.
} 
CORDERO, N. L. Sendo, se é: a tese de Parmênides. Ttrad. E. Wolf. São Paulo: Odysseus, 2011. CORNFORD, F. M. Platón y Parménides. Trad. T. Bretón. Madrid: Visor, 1989.

FORSTER, E. S.; FURLEY, D. J. Aristotle. On sophistical refutations. On coming-to-be and passing-away. On the cosmos (translation). Cambridge/London: Harvard University Press, 1992.

IGLÉSIAS, M. \& RODRIGUES, F. Platão. Parmênides. Rio de Janeiro/São Paulo: PUC/Loyola, 2003.

MURACHCO, H.; MAIA Jr., J.; SANTOS, J. T. Platão. O Sofista. Lisboa: Fundação Calouste Gulbenkian, 2011.

NUNES, C. A. Platão. A República. 3 ed. Belém: EDUFPA, 2016.

PEREIRA, M. H. da R. Platão. A República. 8ed. Lisboa: Fundação Calouste Gulbenkian, 1996.

SCOLNICOV, S. Plato's Parmenides. Berkeley/Los Angeles/London: University of California Press, 2003.

SOARES, M. Nas origens da dialética: as disputas interpretativas entre idealismo e realismo na teoria platônica das Ideias. In: ROHDEN, L. (Org.). Hermenêutica e Dialética: entre Gadamer e Platão. São Paulo: Loyola, 2014, pp.35-63,

TOVAR, A. Platón. El Sofista. (Edición del texto con aparato crítico, traducción, prólogo y notas). Madrid: Instituto de Estudios Políticos, 1970.

YEBRA, V. G. Aristóteles. Metafísica (edición y traducción). 2ed. Madrid: Gredos, 1990. 